\title{
Bimbingan Spiritual untuk Meningkatkan Coping Stress dalam Pandemi Covid-19 pada Pengajian 'Aisyiyah Ranting Kereng Bengkirai
}

\author{
Spiritual Guidance to Improve Coping Stress in the Covid-19 Pandemi in 'Aisyiyah Recitation \\ Kereng Bengkirai Branch
}

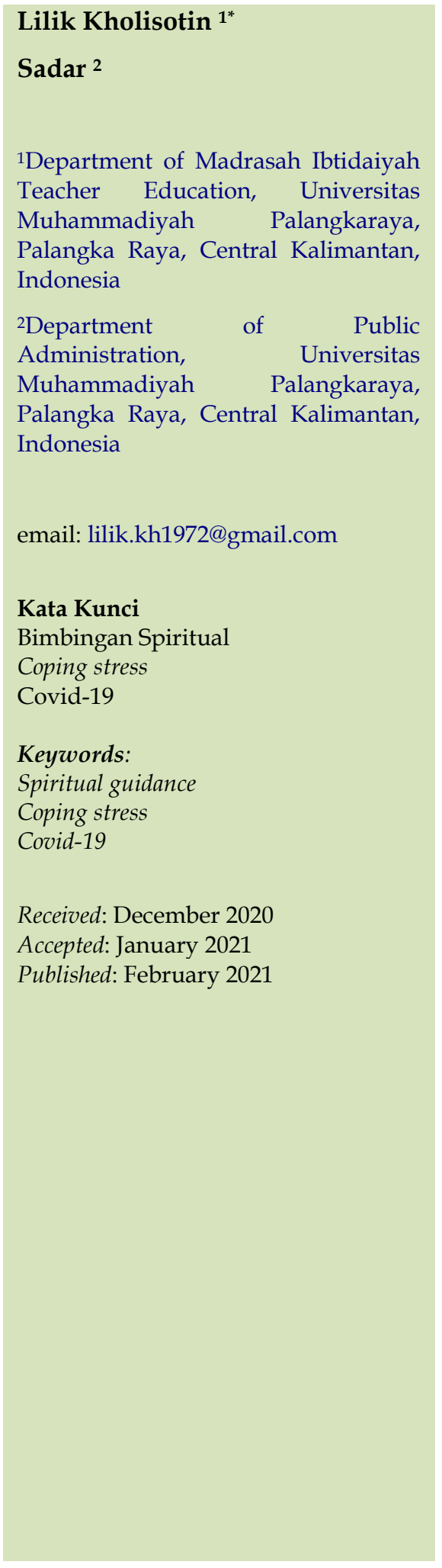

\begin{abstract}
Abstrak
Virus Corona atau severe acute respiratory syndrome coronavirus 2 (SARS-CoV-2) adalah virus yang menyerang sistem pernapasan. Penyakit karena infeksi virus ini disebut Covid-19. Virus Corona bisa menyebabkan gangguan ringan pada sistem pernapasan, infeksi paruparu yang berat, hingga kematian. Persebaran Virus corona yang begitu cepat, menimbulkan ketakutan, keresahan dan beberapa permasalahan sosial lainnya diakalangan masyarakat. Ditambah penerapan berbagai kebijakan pemerintah guna untuk memutus mata rantai persebaran Covid-19 disisi lain ada yang berdampak negatif. Pengabdian masyarakat ini bertujuan untuk memberikan sebuah edukasi kepada masyarakat khususnya pada kelompok pengajiaan Aisyiyah Ranting Kereng Bangkirai berupa sosialisi dan bimbingan spiritual untuk mengurangi kecemasan dan kekhawatiran terhadap Covid-19. Metode pelaksanaan yang ditawarkan merupakan bimbingan spiritual untuk mengatasi masalah stress akibat pandemi covid-19 dengan penyampaian materi dari perspektif Agama Islama dan perspektif Psikologi. Hasil pengabdian menunjukkan adanya kecemasan dikalangan masyarakat akibat covid-19 yang berdampak kepada psikologis dan dampak itu juga mempengaruhi sendi-sendi hidup masyarakat baik social ekonomi, sosial budaya dan sosial agama. Berdasarkan hasil kegiatan yang dilakukan maka dapat disimpulkan bahwa kegiatan pengabdian dapat memberikan dampak positif kepada masyarakat terkait kecemasan yang timbul akibat pandemi covid-19, juga memberikan pemahaman bahwa agama selalu relevan dengan segala kondisi yang timbul di masyarakat.
\end{abstract}

\begin{abstract}
Coronavirus or severe acute respiratory syndrome coronavirus 2 is a virus that attacks the respiratory system. This disease due to viral infection is called COVID-19. The Coronavirus can cause minor disturbances to the respiratory system, severe lung infections, and death. The rapid spread of the coronavirus has caused fear, anxiety, and several other social problems in the community. Besides, the implementation of various government policies to break the chain of distribution of COVID 19, on the other hand, has had a negative impact. This community service aims to provide education to the community, especially in the teaching group Aisyiyah Kereng Bangkirai in the form of socialization and spiritual guidance to reduce anxiety and worry about Covid-19. The implementation method offered is spiritual guidance to deal with stress problems due to the Covid-19 pandemic by delivering material from an Islamic religious perspective and a psychological perspective. The results of this dedication show that there is anxiety among the community due to Covid-19 which has a psychological impact and that impact also affects the joints of community life, both socio-economic, socio-cultural, and socio-religious. Based on the results of the activities carried out, it can be concluded that community service activities can have a positive impact on society regarding the anxiety arising from the Covid-19 pandemic, as well as providing an understanding that religion is always relevant to all conditions that arise in society. Religion is not something rigid but something elastic so that it can always provide solutions to problems that arise.
\end{abstract}




\section{PENDAHULUAN}

Virus Corona atau severe acute respiratory syndrome coronavirus 2 (SARS-CoV-2) adalah virus yang menyerang sistem pernapasan. Penyakit karena infeksi virus ini disebut COVID-19. Virus Corona bisa menyebabkan gangguan ringan pada sistem pernapasan, infeksi paru-paru yang berat, hingga kematian (Mohanty et al. 2020). SARS-CoV-2 yang lebih dikenal dengan nama virus corona adalah jenis baru dari coronavirus yang menular ke manusia. Walaupun lebih bayak menyerang lansia, virus ini sebenarnya bisa menyerang siapa saja, mulai dari bayi, anak-anak, hingga orang dewasa, termasuk ibu hamil dan ibu menyusui (Ovali, 2020). Infeksi virus Corona disebut Covid-19 (Corona Virus Disease 2019) dan pertama kali ditemukan di kota Wuhan, China pada akhir Desember 2019. Virus ini menular dengan sangat cepat dan telah menyebar ke hampir semua negara, termasuk Indonesia, hanya dalam waktu beberapa bulan (Djalante et al., 2020). Hal tersebut membuat beberapa negara menerapkan kebijakan untuk memberlakukan lockdown dalam rangka mencegah penyebaran virus Corona. Di Indonesia sendiri, diberlakukan kebijakan Pembatasan Sosial Berskala Besar (PSBB) untuk menekan penyebaran virus ini (Ristyawati, 2020).

Persebaran Virus corona yang begitu cepat, menimbulkan ketakutan, keresahan dan beberapa permasalahan sosial lainnya diakalangan masyarakat. Ditambah penerapan berbagai kebijakan pemerintah guna untuk memutus mata rantai persebaran Covid-19 disisi lain ada yang berdampak negatif (Syafrida \& Hartati, 2020). Secara umum, meskipun kita ketahui bahwa setiap kebijakan tentu akan melahirkan dua sisi, baik yang positif maupun yang negatif. Dampak negatif yang timbul dari sebuah kebijakan bukan berarti akan diabaikan, namun tentunya pemerintah akan masih terus mencari sosulsi pemasalah guna untuk memberikan pelayanan kepada masyarakat agar tercipta rasa aman dan tentram (Muadi et al., 2016; Aritonang, 2011).

Fenomena akibat wabah Covid-19 ini salah satunya berdampak kepada kejiwaan sebagiaan masyarakat. Beberapa diantaranya bahkan berdampak fatal dengan memilih mengakhiri kehidupannya karena kekhawatiran akibat yang ditimbulkan dari pandemik Covid-19 ini (Sina, 2020). Hampir semua lini sendi-sendi kehidupan bermasyarakat terdampak akibat pandemi Covid-19 ini, baik dari sosial ekonomi, sosial budaya dan bahkan sosial agama (Azimah et al., 2020). Kurangnya edukasi dalam menghadapai pandemik covid 19 sehingga rentan permasalah sosial yang timbul. Oleh karena itu pengabdian kepada masyarakat yang kami selenggarakan ini bertujuan untuk memberikan sebuah edukasi kepada masyarakat khususnya pada kelompok pengajiaan Aisyiyah Ranting Kereng Bangkirai berupa sosialisi dan bimbingan spiritual untuk mengurangi kecemasan dan kekhawatiran terhadap Covid-19.

\section{METODOLOGI}

Kegiatan pelaksanaan Pengabdian Kepada Masyarakat ini dilakukan dengan melibatkan mitra sasaran pada kegiatan bimbingan spiritual untuk meningkatkan copyng stress yakni: kesepakatan menentukan waktu dan tempat pelaksanaan kegiatan, menentukan peserta yang mengikuti program kegiatan Pengabdian Pada Masyarakat serta mengikuti anjuran protocol Kesehatan untuk pencegahan penyebaran covid19 dengan membatasi jumlah peserta dan kewajiban menggunakan masker. Metode pelaksanaan yang ditawarkan merupakan bimbingan spiritual untuk mengatasi masalah stress akibat pandemi covid-19 dengan penyampaian materi dari perspektif Agama Islama dan perspektif Psikologi. 


\section{HASIL DAN PEMBAHASAN}

Pengabdian Kepada Masyarakat yang berjudul "Bimbingan Spiritual Untuk Meningkatkan Coping Stress dalam Pandemi Covid-19 Pada Pengajian 'Aisyiyah Ranting Kereng Bengkirai" dilakukan pada hari Sabtu (25 Juli 2020) di sekolah TK Aisyiyahh 1 Kereng Bengkirai Kota Palangkaraya. Peserta dari kelompok Pengajian Aisyiyah Ranting Kereng Bengkirai sebanyak 30 orang. Adapun narasumber dalam kegiatan pengabdian masyarakat tersebut yaitu Karyanti, M.Pd, dan Lilik Kholisotin, M.Pd.I. (tim pengabdian) kegiatan dilaksanakan mulai pukul 08.30 - 12.30 WIB. Kegiatan dilakukan dalam dua sesi yaitu penyampaian materi bimbingan spiritual dan tanya jawab yang dilakukan dengan audiens, seperti ditunjukkan pada Gambar 1.

Diantara hasil pengabdian yang didapatkan pada pengabdian masyarakat yang mengangkat tema tentang dampak covid terhadap psikologi di masyarakat yaitu diperolehnya informasi bahwa kecemasan yang tinggi dikalangan masyarakat akibat pandemi Covid-19. Salah satu audiens memberikan keterangan bahwa kekhawatirannya terhadap pandemi cukup tinggi sehingga membuatnya tidak bisa bepergian antar wilayah. Selain itu, beberapa diantaranya juga menyampaiakan kekhawatiran yang tinggi sehingga hal itu berdampak negatif dalam perilaku masyarakat.

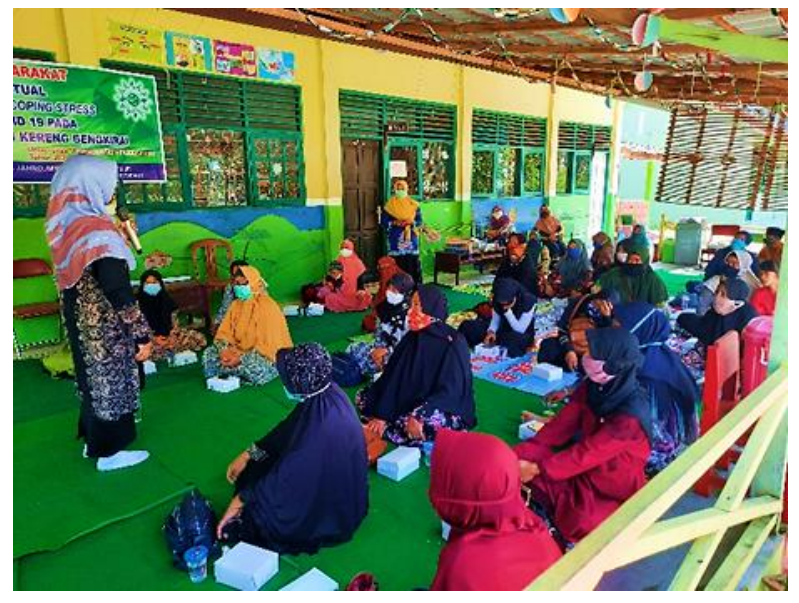

Gambar 1. Pemberian materi I oleh narasumber terkait dengan covid-19 dalam pandangan Psikologi
Tingginya kecemasan dikalangan masyarakat akibat Covid-19 membuat pengaruh terhadap perilaku keseharian. Selain kecemasan akibat pandemi, kecemasan juga timbul akibat berbagai kebijakan yang dikeluarkan oleh pemerintah terkait dengan pencegahan persebaran Covid-19, seperti pembatasan sosial berskala besar (PSBB) dan beberpa kebiajakan lainnya. Mendengar beberapa permasalahan dan kecemasan yang diasampaikan oleh audiens maka pemateri berusaha memberikan berbagai penjelasan dan tips dalam mengatasi kecemasan tersebut (Gambar 2).

Covid-19 selain berdampak terhadap sosial ekonomi, juga berdampak terhadap sosial agama. Kebijakan yang dikeluarkan berkenaan dengan kegiatan peribadatan pada mulanya membuat masyarakat kebingungan karena diperhadapkan dengan kondisi yang tidak lazim. Salahsatu audiens memberikan keterangan bahwa seolah merasa ganjil dengan peribadatan yang dilakukan "saya merasa ritual ibadah saya kurang afdhol" (kata salah seorang audiens). Oleh karena itu bimbingan pada pengabdian masyarakat ini yaitu pandangan agama terkait dengan Covid-19. Mulai dari memaknai wabah tersebut adalah bagian dari ujian Allah serta ikhtiar dalam melawannya sampai kepada bimbingan ritual peribadatan saat menghadapai pandemi.

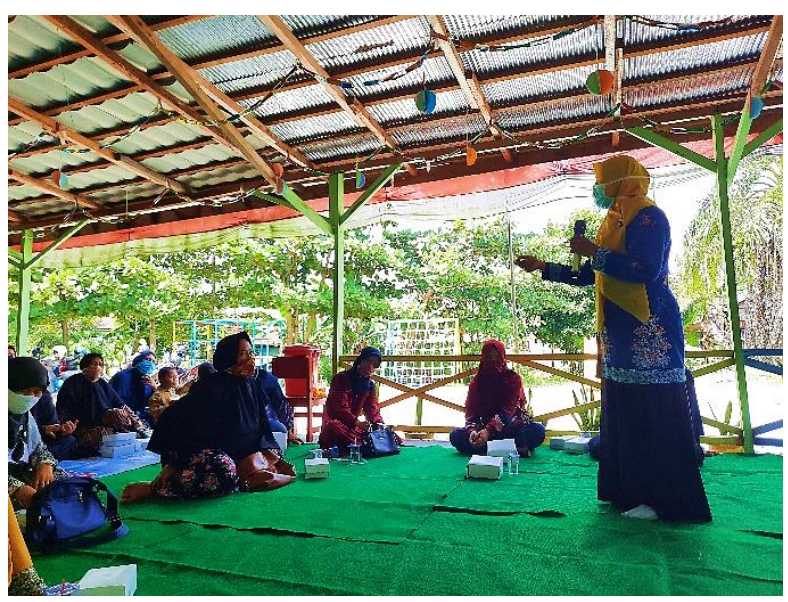

Gambar 2. Pemberian materi 2 oleh narasumber terkait dengan covid-19 dalam pandangan Islam 
Merujuk kepada firman Allah SWT dalam Al-Qur'an surah An-Nisa: 59

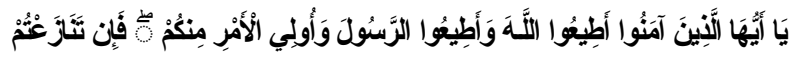

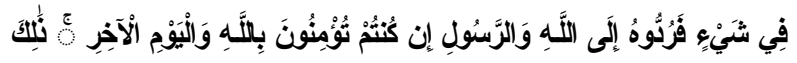

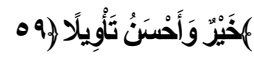

"Wahai orang-orang yang beriman, taatilah Allah dan taatilah Rasul (Nya), dan kepada para pemimpin di antara kamu. Kemudian jika kamu berselisih pendapat tentang sesuatu, maka kembalikanlah ia kepada Allah dan RasulNya, jika kamu benarbenar beriman kepada Allah dan hari akhir. Yang demikian itu lebih utama dan lebih baik akibatnya." (QS. An-Nisa[4]: 59)

Melalui dalil tersebut pemateri menyampaikan kepada para audiens bahwa ummat dianjuran untuk taat atas aturan yang diberlakukan oleh ulil amri. Lebih lanjut juga tidak lupa disampaikan fatwa dari Majelis Ulama Indonesia (MUI) dalam menyikapi pandemi covid-19. Fatwa MUI sebagai berikut:

\section{FATWA}

\section{MAJELIS ULAMA INDONESIA}

\section{Nomor 14 Tahun 2020}

Tentang

\section{PENYELENGGARAN IBADAH DALAM SITUASI TERJADI WABAH COVID-19}

\section{Ketentuan Hukum}

1. Setiap orang wajib melakukan ikhtiar menjaga kesehatan dan menjauhi setiap hal yang diyakini dapat menyebabkannya terpapar penyakit, karena hal itu merupakan bagian dari menjaga tujuan pokok beragama (al-Dharuriyat al-Khams).

2. Orang yang telah terpapar virus Corona, wajib menjaga dan mengisolasi diri agar tidak terjadi penularan kepada orang lain. Baginya shalat Jumat dapat diganti dengan shalat zuhur di tempat kediaman, karena shalat jumat merupakan ibadah wajib yang melibatkan banyak orang sehingga berpeluang terjadinya penularan virus secara massal. Baginya haram melakukan aktifitas ibadah sunnah yang membuka peluang terjadinya penularan, seperti jamaah shalat lima waktu/ rawatib, shalat Tarawih dan Ied di masjid atau tempat umum lainnya, serta menghadiri pengajian umum dan tabligh akbar.

3. Orang yang sehat dan yang belum diketahui atau diyakini tidak terpapar COVID-19, harus memperhatikan hal-hal sebagai berikut:

a. Dalam hal ia berada di suatu kawasan yang potensi penularannya tinggi atau sangat tinggi berdasarkan ketetapan pihak yang berwenang maka ia boleh meninggalkan salat Jumat dan menggantikannya dengan shalat zuhur di tempat kediaman, serta meninggalkan jamaah shalat lima waktu/rawatib, Tarawih, dan Ied di masjid atau tempat umum lainnya.

b. Dalam hal ia berada di suatu kawasan yang potensi penularannya rendah berdasarkan ketetapan pihak yang berwenang maka ia tetap wajib menjalankan kewajiban ibadah sebagaimana biasa dan wajib menjaga diri agar tidak terpapar virus Corona, seperti tidak kontak fisik langsung (bersalaman, berpelukan, cium tangan), membawa sajadah sendiri, dan sering membasuh tangan dengan sabun.

4. Dalam kondisi penyebaran COVID-19 tidak terkendali di suatu kawasan yang mengancam jiwa, umat Islam tidak boleh menyelenggarakan shalat jumat di kawasan tersebut, sampai keadaan menjadi normal kembali dan wajib menggantikannya dengan shalat zuhur di tempat masing-masing. Demikian juga tidak boleh menyelenggarakan aktifitas ibadah yang melibatkan orang banyak dan diyakini dapat menjadi media penyebaran COVID-19, seperti jamaah shalat lima waktu/ rawatib, shalat Tarawih dan Ied di masjid atau tempat umum lainnya, serta menghadiri pengajian umum dan majelis taklim. 
5. Dalam kondisi penyebaran COVID-19 terkendali, umat Islam wajib menyelenggarakan shalat Jumat.

6. Pemerintah menjadikan fatwa ini sebagai pedoman dalam upaya penanggulangan COVID-19 terkait dengan masalah keagamaan dan umat Islam wajib mentaatinya.

7. Pengurusan jenazah (tajhiz janazah) terpapar COVID-19, terutama dalam memandikan dan mengkafani harus dilakukan sesuai protokol medis dan dilakukan oleh pihak yang berwenang, dengan tetap memperhatikan ketentuan syariat. Sedangkan untuk menshalatkan dan menguburkannya dilakukan sebagaimana biasa dengan tetap menjaga agar tidak terpapar COVID-19.

8. Umat Islam agar semakin mendekatkan diri kepada Allah dengan memperbanyak ibadah, taubat, istighfar, dzikir, membaca Qunut Nazilah di setiap shalat fardhu, memperbanyak shalawat, memperbanyak sedekah, dan senantiasa berdoa kepada Allah SWT agar diberikan perlindungan dan keselamatan dari musibah dan marabahaya (doa daf'u al-bala'), khususnya dari wabah COVID-19.

9. Tindakan yang menimbulkan kepanikan dan/atau menyebabkan kerugian publik, seperti memborong dan menimbun bahan kebutuhan pokok dan menimbun masker hukumnya haram.

\section{Rekomendasi}

1. Pemerintah wajib melakukan pembatasan super ketat terhadap keluar-masuknya orang dan barang ke dan dari Indonesia kecuali petugas medis dan import barang kebutuhan pokok serta keperluan emergency.

2. Umat Islam wajib mendukung dan mentaati kebijakan pemerintah yang melakukan isolasi dan pengobatan terhadap orang yang terpapar COVID19 , agar penyebaran virus tersebut dapat dicegah.

3. Masyarakat hendaknya proporsional dalam menyikapi penyebaran COVID-19 dan orang yang terpapar COVID-19 sesuai kaidah kesehatan. Oleh karena itu masyarakat diharapkan menerima kembali orang yang dinyatakan negatif dan/atau dinyatakan sembuh.

\section{Ketentuan Penutup}

1. Fatwa ini mulai berlaku pada tanggal ditetapkan, dengan ketentuan jika di kemudian hari ternyata dibutuhkan perbaikan, akan diperbaiki dan disempurnakan sebagaimana mestinya.

2. Agar setiap muslim dan pihak-pihak yang memerlukan dapat mengetahuinya, semua pihak dihimbau untuk menyebarluaskan fatwa ini.

\section{KESIMPULAN}

Kegiatan yang dilakukan berjalan dengan lancar dan kelompok mitra cukup antusias dengan kegiatan ini. Berdasarkan hasil kegiatan yang dilakukan maka dapat disimpulkan bahwa kegiatan pengabdian dapat memberikan dampak positif kepada masyarakat terkait kecemasan yang timbul akibat pandemi covid-19, juga memberikan pemahaman bahwa agama selalu relevan dengan segala kondisi yang timbul di masyarakat. Agama bukanlah sesuatu yang kaku tetapi sesuatu yang elastis sehingga selalu dapat memberikan soslusi atas permasalahan yang timbul.

\section{UCAPAN TERIMA KASIH}

Terima kasih kami ucapkan kepada semua pihak yang mendukung program ini yakni LP2M UM Palangka Raya selaku penyandang dana program, pengurus Ranting Aisyiyah Kereng Bengkirai, TK Aisyiyah I Kereng Bengkirai tempat pelaksanaan program ini berlangsung serta kelompok Pengajian 'Aisyiyah Ranting Kereng Bengkirai sebagai peserta kegiatan. 


\section{REFERENSI}

Aritonang, A.I. 2011. Kebijakan Komunikasi di Indonesia: Gambaran Implementasi UU No. 14 tahun 2008 tentang Keterbukaan Informasi Publik. Jurnal ASPIKOM. 1(3):261-278. http://dx.doi.org/10.24329/aspikom.v1i3.24

Azimah, R.N., Khasanah, I.N., Pratama, R., Azizah, Z., Febriantoro, W., Purnomo, S.R.S. 2020. Analisis Dampak Covid-19 Terhadap Sosial Ekonomi Pedagang Di Pasar Klaten Dan Wonogiri. Empati: Jurnal Ilmu Kesejahteraan $\begin{array}{ll}\text { Sosial. } & \text { 9(1):59-68. }\end{array}$ https://doi.org/10.15408/empati.v9i1.16485

Departemen Agama Republik Indonesia. 2005. AlQur'an dan Terjemahannya. Surabaya: Duta Ilmu.

Djalante, R., Lassa, J., Setiamarga, D., Sudjatma, A., Indrawan, M., Haryanto, B., Mahfud, C., Sinapoy, M.S., Djalante, S., Rafliana, I., Gunawan, L.A., Surtiari, G.A.K., Warsilah, H. 2020. Review and analysis of current responses to COVID-19 in Indonesia: Period of January to March 2020. Progress in Disaster Science. 6:100091.

https://doi.org/10.1016/j.pdisas.2020.100091

Mohanty, S.K., Satapathy, A., Naidu, M.M., Mukhopadhyay, S., Sharma, S., Barton, L.M., Stroberg, E., Duval, E.J., Pradhan, D., Tzankov, A., Parwani, A.V. 2020. Severe acute respiratory syndrome coronavirus-2 (SARSCoV-2) and coronavirus disease 19 (COVID19) - anatomic pathology perspective on current knowledge. Diagnostic Pathology. 15:103. https://dx.doi.org/10.1186/s13000020-01017-8

Muadi, S., Ismial, M.H., Sofwani, A. 2016. Konsep Dan Kajian Teori Perumusan Kebijakan Publik. JRP (Jurnal Review Politik). 6(2):195-224.

Ovali, F. 2020. SARS-CoV-2 Infection and the Newborn. Frontiers in Pediatrics. 8:294. https://dx.doi.org/10.3389/fped.2020.00294

Ristyawati, A. 2020. Efektifitas Kebijakan Pembatasan Sosial Berskala Besar Dalam Masa Pandemi Corona Virus 2019 oleh Pemerintah Sesuai Amanat UUD NRI Tahun 1945. Administrative Law and Governance Journal. 3(2):240-249. https:/ /doi.org/10.14710/alj.v3i2.240-249
Sina, P.G. 2020. Ekonomi Rumah Tangga Di Era Pandemi Covid-19. Journal of Management: Small and Medium Enterprises (SMEs). 12(2):239254. https://doi.org/10.35508/jom.v12i2.2697

Syafrida, S., Hartati, R. 2020. Bersama Melawan Virus Covid 19 di Indonesia. Salam: Jurnal Sosial dan Budaya Syar-i. 7(6):495-508. https://doi.org/10.15408/sjsbs.v7i6.15325 